\title{
PENALARAN MAHASISWA CALON GURU MATEMATIKA YANG MEMILIKI GAYA BERPIKIR SEKUENSIAL ABSTRAK DALAM MENYELESAIKAN SOAL HOTS
}

\author{
Tri Bondan Kriswinarso ${ }^{1}$; Suaedi ${ }^{2}$; Ma'rufi $^{3}$ \\ Universitas Cokroaminoto Palopo ${ }^{1,2,3}$ \\ triebondankris@gmail.com¹,Suadif@gmail.com², Marufi.ilyas@gmail.com³
}

\begin{abstract}
Abstrak
Problem penelitian ini adalah kemampuan penalaran Mahasiswa dalam Menyelesaikan Soal High Order Thinking Skill di materi sistem persamaan linear tiga variabel. Penelitian ini bertujuan untuk mendeskripsikan penalaran mahasiswa calon guru matematika yang memiliki gaya berpikir sekuensial abstrak. Penelitian ini dilaksanakan di program studi Pendidikan Matematika FKIP UNCP. Metode yang digunakan dalam penelitian ini adalah metode deskriptif dengan pendekatan kualitatif dan data dalam penelitian ini diperoleh dari tes dan wawancara. Hasil penelitian ini menunjukkan kemampuan penalaran matematika subjek dengan gaya berpikir sekuensial abstrak dalam menyelesaikan Soal High Order Thinking Skill cenderung memenuhi semua indikator kemampuan penalaran, Dalam mengajukan dugaan, subjek mampu menjelaskan banyak dugaan dalam menyelesaikan SPLTV baik menggunakan metode subtitusi, eliminasi, matriks ataupun grafik. Selain itu, subjek menjelaskan dugaan dalam membentuk persamaan pecahan dengan pendekatan perbandingan berbalik.
\end{abstract}

Kata kunci: Penalaran, HOTS, Gaya Berpikir.

\section{A. Pendahuluan}

Kemajuan teknologi dan ilmu pengetahuan berkembang sangat cepat, hal tersebut yang menjadi tantangan untuk dunia pendidikan di negara Indonesia. Dunia pendidikan di masa yang akan datang mampu mendukung pembangunan, seperti yang dikemukakan Trianto (2009) bahwa pendidikan mampu mengembangkan potensi siswa. Kebijakan Pendidikan Nasional dalam menyongsong pasar global harus mampu meningkatkan kualitas pendidikan, secara akademik ataupun nonakademik.

Menurut Ilyas (2015), pendidikan merupakan suatu kegiatan yang berintikan interaksi antara peserta didik dengan para pendidik serta berbagai sumber pendidikan. Interaksi antara peserta didik dengan pendidik dan sumber-sumber pendidikan 
tersebut dapat berlangsung dalam situasi pergaulan (pendidikan), pengajaran, latihan, serta bimbingan. Situasi pergaulan pendidikan tersebut biasa disebut pergaulan edukatif. Interaksi edukatif yang terjadi dalam proses pendidikan atau proses pembelajaran peserta didik sangat mempengaruhi proses pembelajaran untuk mencapai tujuan yang diharapkan dalam pendidikan.

Seperti yang tertuang dalam Undang-undang Nomor 20 Tahun 2003 tentang Sistem Pendidikan Nasional pasal 3 sebagai berikut: "Pendidikan nasional berfungsi untuk mengembangkan kemampuan dan membentuk watak serta peradaban bangsa yang bermartabat dalam rangka mencerdaskan kehidupan bangsa. Pendidikan nasional bertujuan untuk mengembangkan potensi peserta didik agar menjadi manusia yang beriman dan bertakwa kepada Tuhan yang maha kuasa, berahlak mulia, sehat, berilmu, cakap, kreatif, mandiri dan menjadi warga negara yang demokratis serta bertanggung jawab.

Matematika merupakan disiplin ilmu yang memiliki ciri khas tersendiri dibandingkan dengan disiplin ilmu yang lainnya. Karakteristik dari matematika yaitu disiplin ilmu yang memiliki objek abstrak, objek/konsep saling berkaitan dan bersifat hirarkis serta konsisten, pembahasannya memerlukan keterampilan algoritma dan perhitungan serta dapat diterapkan dalam berbagai aspek ilmu maupun dalam kehidupan sehari-hari. Hal ini mengakibatkan, dalam belajar matematika memerlukan penalaran yang yang baik dan benar untuk dapat memahami langkah serta penyelesaian dari masalah yang dapat timbul.

TIMSS pada tahun 2011 menitikberatkan pada kemampuan knowing (pengetahuan) sebanyak 35\%, applying (penerapan) sebanyak 40\%, dan reasoning (penalaran) sebanyak 25\% (Mullis, Martin, Foy, \& Arora, 2012). Hal ini diperkuat juga dengan pendapat Winataputra (Riadi \& Retnawati, 2014) tentang penelitian TIMSS yang menunjukkan masih rendahnya prestasi siswa Indonesia dalam matematika, terutama terkait soal-soal High Order Thinking Skills (HOTS). Anderson \& Krathwohl (2017) menyatakan HOTS merupakan suatu keterampilan berpikir yang tidak hanya membutuhkan keterampilan mengingat, tetapi membutuhkan keterampilan lain yang lebih tinggi. Indikator untuk mengukur HOTS 
meliputi keterampilan menganalisis, mengevaluasi, dan menciptakan (Mandini \& Hartono, 2018).

Pembelajaran dikatakan berkualitas tinggi atau baik apabila tujuan dari pembelajaran yang telah ditetapkan tercapai dengan baik. Salah satu faktor yang dapat mempengaruhi peserta didik dalam belajar serta mencapai prestasi adalah cara gaya berpikir yang digunakan ketika proses pembelajaran berlangsung. Sudjana (2005) mengatakan ada beberapa perbedaan gaya berpikir yaitu "Setiap orang memiliki gaya berpikir masing-masing yang dapat diidentifikasi, dimanfaatkan dan dikembangkan keunggulannya, serta diperkuat sehingga setiap orang menjadi peserta didik yang lebih berhasil dalam belajarnya". Sejalan dengan itu Santrock (2004) gaya belajar dan gaya berpikir merupakan suatu cara yang dipilih seseorang dalam menggunakan kemampuannya.

Pendekatan yang dilakukan oleh Gregorc untuk mengetahui Mind Style, adalah pendekatan berdasarkan pemrosesan informasi. Gregorc menyatakan bahwa ada perbedaan dalam cara orang memahami (menerima, menyerap) informasi. Kemampuan untuk memahami ini dikatakan sebagai 'Persepsi' dan juga perbedaan dalam hal menata (mengorganisir, menyimpan dan mereferensi) informasi. Kemampuan menata ini disebut sebagai 'Pengaturan'. Gregorc (Deporter \& Hernacki, 2015) mengelompokkan gaya berpikir menjadi 4 bagian yaitu sekuensial konkret, sekuensial abstrak, acak konkret dan acak abstrak.

Berdasarkan hasil tes awal yang dilakukan pada 06 Desember 2019, pada mahasiswa program studi pendidikan matematika FKIP UNCP sebanyak 37 orang mahasiswa dalam menyelesaikan sebuah permasalahan/ soal terlihat bahwa mahasiswa memiliki kemampuan penalaran yang berbeda-beda. Dalam menyelesaikan masalah yang diberikan terlihat bahwa hanya terdapat 4 indikator penalaran yang nampak dari hasil kerja mahasiswa diantaranya 1) Menyajikan pernyataan matematika secara lisan, tertulis, gambar; 2) Mengajukan dugaan; 3) Melakukan manipulasi matematika; 4) Menyusun bukti dan memberikan alasan terhadap kebenaran solusi; sedangkan bagian indikator penalaran tentang Menarik kesimpulan dari pernyataan dan memeriksa kesahihan suatu argument tidak nampak. 
Adapun dalam penelitian ini mencoba untuk mengungkap indikator yang belum nampak sehingga peneliti berkeinginan untuk melakukan penelitian dengan judul "Penalaran Mahasiswa Calon Guru Matematika yang memiliki gaya berpikir sekuensial abstrak dalam Menyelesaikan Soal High Order Thinking Skills (HOTS)".

Berdasarkan uraian latar belakang yang telah dikemukakan maka pertanyaan penelitian yang muncul adalah bagaimanakah penalaran mahasiswa calon guru matematika yang memiliki gaya berpikir Tipe Sekuensial Abstrak dalam menyelesaikan soal High Order Thinking Skills (HOTS)?. Sehingga tujuan dari penelitian ini adalah mendeskripsikan penalaran mahasiswa calon guru matematika yang memiliki gaya berpikir Tipe Sekuensial Abstrak dalam menyelesaikan soal High Order Thinking Skills (HOTS).

\section{B. Metode Penelitian}

Penelitian ini adalah penelitian deskriptif dengan menggunakan pendekatan kualitatif atau dinamakan penelitian deskriptif kualitatif. Subjek dalam penelitian ini adalah mahasiswa Program Studi Pendidikan Matematika FKIP UNCP angkatan 2018. Penetapan subjek ini berdasarkan hasil tes penentuan gaya berpikir. Banyak subjek dalam penelitian sebanyak satu orang yang memiliki gaya berpikir sekuensial abstrak. Adapun langkah-langkah penentuan subjek sebagai berikut:

1. Memberikan kuesiner gaya berpikir

2. Menganalisis hasil kuesioner gaya berpikir

3. Mengelompokkan setiap calon subjek penelitian berdasarkan gaya berpikir

4. Memilih calon subjek untuk dijadikan subjek penelitian berdasarkan gaya berpikir SA. Hasil Pengelompokan ini dapat dilihat pada tabel 2 berikut:

Tabel 2. Hasil Pengelompokan gaya berpikir

\begin{tabular}{ccc}
\hline Kategori Gaya Berpikir & Banyak mahasiswa & Persentase $(\%)$ \\
\hline Acak Abstrak & 19 & 38 \\
Acak Konkret & 5 & 10 \\
Sekuensial Abstrak & 9 & 18 \\
Sekuensial Konkret & 17 & 24 \\
\hline
\end{tabular}


5. $\frac{\text { Jumlah }}{100}$ berdasarkan pertimbangan dosen. Mahasiswa yang ditetapkan sebagai subjek dapat dilihat pada tabel 3 berikut.

Tabel 3. Hasil Pengelompokan gaya berpikir

\begin{tabular}{ccc}
\hline Kategori Gaya Berpikir & Inisial Subjek & Kode \\
\hline Sekuensial Abstrak & FA & SA \\
\hline
\end{tabular}

Instrumen yang digunakan dalam penelitian ini terbagi 2 yaitu instrumen utama dan instrumen pendukung (tes gaya berpikir, tes kemampuan penalaran matematika dan pedoman wawancara). Langkah-langkah yang dilakukan dalam pengumpulan data adalah sebagai berikut:

a. Subjek diberikan soal HOTS, setiap langkah penyelesaian ditunjukkan subjek, peneliti mengajukan pertanyaan yang berkaitan kesimpulan subjek tersebut. Data yang terkumpul berupa hasil pekerjaan subjek, dan hasil wawancara. Hasil wawancara direkam dan dibuat transkrip wawancara yang dilengkapi kode.

b. Melakukan reduksi, abstraksi, transformasi dan pengkategorian pada tes Setelah data terkumpul maka dilakukan pemeriksaan keabsahan data. Keabsahan data merupakan konsep penting dalam penelitian kualitatif. Pemeriksaan terhadap keabsahan data bertujuan untuk mengurangi bias yang terjadi pada saat pengumpulan data. Dengan pemeriksaan keabsahan data peneliti akan lebih yakin bahwa data yang diperoleh benar-benar valid dan reliabel. Agar data yang diperoleh bisa memperoleh keabsahan data, maka dalam penelitianini teknik pemeriksaan keabsahan data dilakukan dengan menggunakan teknik Triangulasi.

Data yang telah terkumpul dan masih dalam bentuk rekaman, selanjutnya ditransformasi ke dalam bentuk transkrip wawancara. Hasil transkrip dan hasil tugas pemecahan masalah matematika dianalisis dengan langkah-langkah sebagai berikut 1) Menelaah seluruh data yang tersedia dari berbagai sumber; 2) Reduksi data; 3) Penyajian data; 4) Membuat coding atau kode; 5) Memaparkan data hasil wawancara dari hasil tes penalaran menyelesaikan soal HOTS mahasiswa; 6) Menafsirkan 
data/menarik kesimpulan penelitian dari data yang sudah dikumpulkan dan memverifikasi kesimpulan tersebut.

\section{Hasil Penelitian dan Pembahasan}

Berdasarkan hasil tes dan wawancara dengan subjek, berikut dipaparkan Penalaran matematika SA dalam menyelesaikan soal HOTS berdasarkan indikatorindikator penalaran. Adapun uraian selengkapnya dapat dilihat pada tabel-tabel berikut.

Tabel 4. Menyajikan pernyataan matematika secara lisan, tertulis, gambar dan diagram Data Valid Kode

Subjek mampu menjelaskan dan menuliskan penyajian dalam bentuk model matematika dengan membuat model matematika dengan menyusun 3 persamaan linear tiga variabel DV-SA-01 yaitu $A+2 B+3 C=20.000,2 A+3 B=19.000$ dan $B+C=6.250$

Subjek mampu menjelaskan penyajian dalam bentuk model, gambar, faktor, sifat hubungan yang terdapat pada soal dengan menjelaskan Subjek menjelaskan bahwa soal nomor dua merupakan SPLTV dengan perbandingan berbalik nilai. Kemudian subjek DV-SA-02 membuat dua persamaan yaitu $\frac{1}{x}+\frac{1}{y}+\frac{1}{z}=\frac{1}{10}$ dan $\frac{1}{y}+\frac{1}{z}=\frac{1}{15}$

Tabel 5. mengajukan dugaan

$$
\text { Data Valid }
$$

Kode

Subjek menuliskan dan menjelaskan pemisalan jenis beras A saya tuliskan A, jenis beras B saya tuliskankan B dan jenis beras C saya tuliskan C. Lalu subjek menjelaskan dalam menyelesaiakan soal subjek menggunakan metode subtitusi

Subjek memisalkan Joni dalam X jam, Deni dalam Y jam dan Ari dalam Z jam, dengan cara perbandingan kemudian subjek menyusun 2 persamaan yaitu $\frac{1}{x}+\frac{1}{y}+\frac{1}{z}=\frac{1}{10}$ dan $\frac{1}{y}+\frac{1}{z}=\frac{1}{15}$. Kemudian subjek mengatakan bahwa yang ditanyakan yaitu berapa jam waktu yang mereka gunakan masing-masing baik Deni, Ari dan Joni dalam mengecat rumah jika bekerja sendirisendiri

Tabel 6. melakukan manipulasi matematika

\section{Data Valid}

Kode

Subjek menuliskan dan menjelaskan langkah dalam menyelesaikan soal dengan membuat persamaan $A+2 B+3 C=19500,2 A+3 B=19000$ dan $B+C=6250$ kemudian subjek mengubah persamaan dua dan tiga menjadi $A=\frac{19000-3 B}{2}$ dan $C=6250-B$. Selanjutnya subjek melakukan subtitusi sehingga memperoleh nilai $B=3500, C=2750$ dan $A=4250$

Subjek menuliskan dan menjelaskan langkah dalam menyelesaikan soal dengan menggunakan konsep metode substitusi dan perbandingan berbalik. subjek membuat model matematika yaitu $\frac{1}{x}+\frac{1}{y}+\frac{1}{z}=\frac{1}{10}$ dan $\frac{1}{y}+\frac{1}{z}=\frac{1}{15}$ kemudian melakukan subtitusi sehingga memperoleh nilai $\mathrm{x}=30$. Kemudian subjek menjelaskan dengan dasar perbandingan berbalik saya memperoleh persamaan $\frac{1}{x}+\frac{1}{y}=\frac{1}{\frac{40}{3}}$, setelah itu subjek kembali mensubtitusi dengan DV-SA-06 memperoleh nilai $\mathrm{y}=24$ dan $\mathrm{z}=40$

Tabel 7. menyusun bukti dan memberikan alasan terhadap kebenaran solusi

\begin{tabular}{cc}
\hline Data Valid & Kode \\
\hline Subjek menjelaskan proses berpikir dalam menyelidiki soal sehingga menemukan solusi yang & DV-SA-07 \\
\hline
\end{tabular}


digunakan dengan menjelaskan bahwa sebelumnya harus ditentukan berapa harga untuk $1 \mathrm{~kg}$ beras jenis A, harga $1 \mathrm{~kg}$ beras jenis B dan harga $1 \mathrm{~kg}$ beras jenis C. Setelah memperoleh ketiga jenis beras tersebutmak dibandingkan, apakah benar jenis A itu yang paling mahal dan setelah melakukan metode subtitusi diperoleh bahwa pernyataan itu memang benar bahwa harga beras jenis A yang paling mahal dari pada harga beras jenis $\mathrm{B}$ dan $\mathrm{C}$

Subjek menjelaskan dengan menggunakan perbandingan berbalik diperoleh persamaan, $\frac{1}{x}+$ $\frac{1}{y}=\frac{1}{\frac{3}{5}} x 8 \rightarrow \frac{1}{x}+\frac{1}{y}=\frac{1}{\frac{40}{3}}$. Sehingga diperoleh nilai $\mathrm{y}=24$. Kemudian mensubtitusi y ke DV-SA-08 persamaan $\frac{1}{y}+\frac{1}{z}=\frac{1}{15}$ sehingga memperoleh nilai $\mathrm{z}$ adalah 40

Tabel 8. menarik kesimpulan dari pernyataan

\begin{tabular}{lc}
\hline \multicolumn{1}{c}{ Data Valid } & Kode \\
\hline $\begin{array}{l}\text { Subjek menuliskan dan menjelaskan memperoleh nilai A, B dan C kemudian dibandingkan. } \\
\text { Karena hasil yang diperoleh nilai yang paling tinggi adalah nilai A yaitu 4.250 maka otomatis } \\
\text { itulah yang paling mahal dibandingkan nilai B 3500 dan nilai C }\end{array}$ & DV-SA-09 \\
\hline $\begin{array}{l}\text { Subjek menjelaskan bahwa kesimpulannya ketika mereka mengecat rumah bagian luar secara } \\
\text { sendiri-sendiri, untuk Joni membutuhkan waktu 30 Jam, Deni 24 Jam dan Ari 40 jam }\end{array}$ & DV-SA-10 \\
\hline
\end{tabular}

Tabel 9. memeriksa kesahihan suatu argumen

\begin{tabular}{lc}
\hline \multicolumn{1}{c}{ Data Valid } & Kode \\
\hline $\begin{array}{l}\text { Subjek menjelaskan bahwa telah memperoleh hasilnya maka disubtitusikan kembali nilai } \\
\text { tersebut ke persamaan yang diketahui yaitu } \mathrm{A}+2 \mathrm{~B}+3 \mathrm{C}=19.500 \text { dan setelah cocok hasilnya } \\
\text { saya yakin bahwa jawaban saya sudah benar }\end{array}$ & DV-SA-11 \\
\hline $\begin{array}{l}\text { Subjek mengatakan bahwa saya yakin dengan jawaban saya karena saya mengerjakan } \\
\text { dengan analisa saya sendiri }\end{array}$ & DV-SK-12 \\
\hline
\end{tabular}

Berdasarkan hasil pengerjaan tes uraian dan hasil wawancara, setiap subjek menunjukkan respon yang baik selama mengerjakan soal. Ketika melaksanakan indikator pertama tentang menyajikan pernyataan matematika secara lisan, tertulis dan gambar, subjek begitu antusias dan penjelasan yang diberikanpun mudah dipahami. Subjek mampu menjelaskan informasi dalam soal dan proses berpikir dalam menyederhanakan dan menyajikan yang diketahui dari soal dengan menggunakan model matematika dalam menyelesaikan soal. Subjek memberikan jawaban yang benar dengan cara mencermati serta mengolah informasi penting dan berdasarkan informasi-informasi yang telah dipadukan. Hal ini menunjukkan bahwa subjek mampu memahami apa yang diinginkan dalam setiap soal. Hal ini sejalan dengan pendapat Wardhani (Pahmi, 2016) yang menyatakan bahwa kegiatan yang tergolong penalaran ialah memberi penjelasan model, fakta, sifat, hubungan atau pola yang ada. Namun dari keempat subjek 
Pada indikator kedua yaitu kemampuan mengajukan dugaan, subjek dapat menjelaskan proses berpikir dalam menemukan dan membuat dugaan terhadap jawaban atau penyelesaian setiap soal serta menjelaskan apa yang diketahui, ditanya dari setiap soal dan proses mengerjakannya. Dalam mengajukan dugaan subjek menjelaskan berbagai macam jenis dugaan dalam menyelesaiakan soal tersebut. Diantara dua metode yang umumnya dilakukan yaitu eliminasi dan subtitusi subjek mampu menjelaskan metode lain dalam menyelesaikan soal tersebut dengan mengungkapkan dapat menyelesaikan soal tersebut dengan metode matriks ataupun grafik. Selain itu, di soal nomor 2 menyatakan soal merupakan persamaan tiga variabel namun didalamnya terdapat konsep perbandingan berbalik yaitu perbandingan dari dua atau lebih besaran dimana suatu variabel bertambah, maka variabel yang lain berkurang atau turun nilainya. Ini menggambarkan bahwa subjek tidak mengalami kesulitan untuk menuliskan hal yang abstrak. Hal ini sejalan dengan Fitriani, Agoestanto, \& Hendikawati (2019) menyatakan bahwa tipe Sekuensial Abstrak (SA) memiliki daya imajinasi yang kuat, pada umumnya menangkap informasi secara abstrak.

Pada indikator ketiga yaitu melakukan manipulasi matematika, subjek dapat menjelaskan proses berpikir dalam menyelesaikan permasalahan dengan menggunakan cara sehingga tercapai tujuan, dengan cara melakukan langkah-langkah penyelesaian soal. Sehingga subjek dapat menarik kesimpulan dengan benar dari pernyataan yang diberikan atau dari penyelesaian setiap soal yang dituliskan sesuai dengan langkah-langlah yang digunakan. Meskipun dalam menyelesaikan soal nomor 2 subjek tidak langsung membuat model persamaan melainkan melakukan penyusunan dan penyederhanaan persamaan ketiga sesuai dengan pemahaman subjek masing-masing, namun subjek menyadari akan hal itu dan memberikan penjelasan terhadap langkah yang mereka lakukan. Hal ini didukung oleh Kurtz, et al (Absorin \& Sugiman, 2018) yang menyatakan bahwa salah satu aspek dalam penalaran adalah proses kognitif seseorang yang memulainya dengan informasi menuju pada penarikan suatu kesimpulan atas informasi tersebut. 
Pada indikator keempat yaitu menyusun bukti dan memberikan alasan terhadap kebenaran solusi, subjek dapat menuliskan dan menjelaskan proses berpikir dalam menyusun bukti terhadap kebenaran solusi dan memberikan alasan terhadap kebenaran solusi serta mampu menyelidiki soal sehingga menemukan solusi yang digunakan. Hanya solusi dari soal nomor 2 yang subjek kurang yakini, dimana setiap subjek menjelaskan bahwa dirinya tidak mampu langsung membuat pemodelan dalam persamaan ketiga. Hal ini dikarenakan subjek tidak memahami bagian dari pernyataan soal sehingga subjek mengerjakan dengan langkahnya masing-masing berdasarkan dengan pernyataan soal yang diberikan dan yang mereka pahami. Namun setiap subjek mampu menjelaskan cara menyelesaikan soal tersebut karena langkah tiap langkah dalam menyederhanakan penyeselaian dikerjakan dengan teliti sehingga membentuk persamaan yang lebih sederhana dan dapat lebih dipahami. Hal ini memenuhi karakteristik soal penalaran, dimana menurut Ikram (2013) salah satu karakter soal penalaran adalah mengungkapkan alasan kebenaran suatu pernyataan, dengan cara menyusun bukti terhadap kebenaran solusi.

Pada indikator kelima yaitu menarik kesimpulan dari suatu pernyataan, subjek dapat menjelaskan proses berpikir dalam menarik kesimpulan dari penyelesaian soal yang subjek kerjakan. Subjek dapat menarik kesimpulan terhadap penyelesaian yang diberikan dengan benar dan lengkap jawaban dari soal nomor 1 dan soal nomor 2, namun pada soal nomor 2 subjek hanya dapat menyimpulkan sebagian. Hal ini memenuhi karakteristik soal penalaran, dimana dijelaskan bahwa penalaran adalah suatu cara berpikir yang menghubungkan antara dua hal atau lebih berdasarkan sifat dan aturan tertentu yang telah diakui kebenarannya menggunakan langkah-langkah pembuktian hingga mencapai suatu proses mental dalam menarik kesimpulan (generalization) dengan alasan-alasan yang sah (Amir, 2018)

Pada indikator keenam yaitu memeriksa kesahihan suatu argumen, dalam menuliskan dan menjelaskan proses berpikir dalam memeriksa hasil jawaban serta menyelidiki benar tidaknya argumen/pernyataan, setiap subjek melakukan pengecekan ulang guna memastikan kebenaran jawaban yang diperoleh. Namun hal tersebut hanya subjek jelaskan bahwa dirinya memeriksa kembali kebenarannya, 
namun tidak menuliskannya pada lembar jawaban. Berdasarkan hasil penelitian diperoleh bahwa subjek dengan gaya berpikir SA memiliki kecenderuan kemampuan penalaran matematika yang baik. Hal ini didukung dengan penelitian sebelumnya yakni Susanti, Said \& Aisyah (2017) juga menyatakan bahwa penalaran yang mempunyai gaya berpikir sekuensial abstrak mempunyai tingkat kemampuan penalaran yang tinggi dengan skor 87.3.

\section{Kesimpulan}

Kemampuan penalaran matematika mahasiswa SA dalam menyelesaikan soal HOTS pada materi SPLTV cenderung memenuhi semua indikator kemampuan penalaran. Dalam mengajukan dugaan, subjek mampu menjelaskan banyak dugaan dalam menyelesaikan SPLTV baik menggunakan metode subtitusi, eliminasi, matriks ataupun grafik. Selain itu, subjek menjelaskan dugaan dalam membentuk persamaan pecahan dengan pendekatan perbandingan berbalik.

\section{Daftar Pustaka}

Absorin, \& Sugiman. (2018). Eksplorasi Kemampuan Penalaran dan Representasi Matematis Siswa Sekolah Menengah Pertama. Pythagoras: Jurnal Pendidikan Matematika, 189-202.

Amir, A. (2018). Penalaran Matematik melalui Pendekatan Open Ended dalam Pembelajaran Matematika. Logartitma Vol. 06 No. 01, 1-18.

Anas, A. (2014). Pengaruh Persepsi Siswa tentang Peran Guru, Gaya Belajar dan Gaya Berpikir terhadap Hasil Belajar Matematika Siswa Kelas VII SMP Negeri di Kabupaten Soppeng. Tesis tidak diterbitkan. Makassar: Universitas Negeri Makassar.

Anderson, L. W., \& Krathwohl, D. R. (2017). Kerangka Landasan untuk Pembelajaran, Pengajaran dan Asesmen Revisi Taksonomi Pendidikan Bloom. Yogyakarta: Pustaka Pelajar.

Ariyana, Y., Pudjiastuti, A., Bestary, R., \& Zamroni. (2019). Buku Pegangan Pembelajaran Berorientasi pada Keterampilan Berpikir Tingkat Tinggi. Jakarta: Direktorat Jenderal Guru dan Tenaga Kependidikan Kementrian Pendidikan dan Kebudayaan. 
Brodie, K. (2010). Teaching Mathematical Reasoning in Secondary School Classroom. New York: Springer.

Deporter, B., \& Hernacki, M. (2015). Quantum Learning Membiasakan Belajar Nyaman dan Menyenangkan. Bandung: Kaifa.

Fitriani, N. N., Agoestanto, A., \& Hendikawati, P. (2019). Kemampuan Penalaran Matematis dan Kemandirian Peserta Didik Kelas X Ditinjau Dari Gaya Berpikir dalam Pembelajaran Core. PRISMA, Prosiding Seminar Nasional Matematika2, 452-465.

Handayani, T. R., Ummah, S. K., \& Utomo, D. P. (2019). Analisis Gaya Berpikir Matematis Berdasar Teori Mental-Self Goverment (MSG) ditinjau dari Dimensi Pembelajaran Sternberg. Jurnal Ilmiah Pendidikan MAtematika (JIPM) 7 (2), 93103.

Helmawati. (2019). Pembelajaran dan Penilaian Berbasis HOTS (High Order Thinking Skills). Bandung: PT. Remaja Rosdakarya.

Ikram, M. (2013). Eksplorasi Penalaran Siswa dalam Pemecahan Masalah Trigonometri ditinjau dari Kemampuan Berpikir Logis pada Siswa Kelas XIIIPA. Tesis tidak diterbitkan. Makassar: Universitas Negeri Makassar.

Ilyas, M. (2015). Metodologi Penelitian Pendidikan Matematika Dilengkapi Beberapa Contoh Hasil Penelitian dengan Paradigma Yang Berbeda. Bandung: Global Researh and Consulting Institute.

Linola, D. M., Marsitin, R., \& Wulandari, T. C. (2017). Analisis Kemampuan Penalaran Matematis Peserta Didik dalam Menyelesaikan Soal Cerita di SMAN 6 Malang. Pi: Mathematics Education Journal, 1 (1), 27-33.

Mandini, G. W., \& Hartono, H. (2018). Analisis Kemampuan Menyelesaikan Soal HOTS Model TIMSS dan Kepercayaan Diri Siswa Sekolah Menengah Pertama. Phytagoras: Jurnal Pendidikan Matematika 13 (2), 148-157.

Ma'rufi. (2011). Kemampuan Matematika dan Gaya Berpikir Mahasiswa (Studi pada Mahasiswa Prodi Pendidikan Matematika FKIP UNCP). Jurnal Dinamika 02 (2), 28-44.

Mullis, I. V., Martin, M. O., Foy, P., \& Arora, A. (2012). TIMSS 2011 International Results in Mathematics Chestnut Hill, MA: TIMSS \& PIRLS International

Novianti, D. (2014). Analisis Kemampuan Berpikir Tingkat Tinggi Siswa dengan Gaya Belajar Tipe Investigasi dalam Pemecahan Masalah Matematika kelas VII di SMP N 10 Kota Jambi. Artikel ilmiah Universitas Negeri Jambi. 
Nurhayati, S., Sutinah, \& Rosyidi, A. H. (2013). Kemampuan Penalaran Siswa Kelas VIII dalam Menyelesaikan Soal Kesebangunan . MATHEdunesa 2(1).

Pahmi, S. (2016). Meningkatkan Kemampuan Penalaran dan Pemecahan Masalah Matematik Serta Minat Belajar Siswa SMK melalui Metode Penemuan. Tesis tidak diterbitkan. Bandung: Sekolah Tinggi Keguruan dan Ilmu Pendidikan (STKIP) Siliwangi Bandung.

Riadi, A., \& Retnawati, H. (2014). Pengembangan Perangkat Pembelajaran untuk Meningkatkan . PYTHAGORAS: Jurnal Pendidikan Matematika 9 (2), 126135 .

Santrock, J. W. (2004). Psikologi Pendidikan. Jakarta: Kencana Predana Media Group.

Setiawati, W., Asmira, O., Ariyana, Y., Bestary, R., \& Pudjiastuti, A. (2019). Buku Penilaian Berorientasi High Order Thinking Skills. Jakarta: Direktorat Jenderal Guru dan Tenaga Kependidikan Kementerian Pendidikan dan Kebudayaan.

Subanji. (2007). Proses Berpikir Kovariasional Pseudo Dalam Mengkonstruksi Grafik Fungsi Kejadian Dinamika Berkebalikan. Disertasi tidak dipublikasikan. Surabaya: Universitas Negeri Surabaya.

Sudjana, D. (2005). Strategi Pembelajaran. Bandung: Falah Production.

Trianto. (2009). Mendesain Model Pembelajaran Inovatif-Progresif. Jakarta: Kencana Prenada Media Group. 